\title{
Design Criterion of Reinforcement on Thick Soft Clay Foundations of Traditional Construction Method in Indonesia
}

\author{
Suyuti Nurdin ${ }^{1, *}$, Kazuhide Sawada ${ }^{1}$, and Shuji Moriguchi ${ }^{2}$ \\ ${ }^{1}$ Laboratory of Geotechnical Engineering, Faculty of Engineering, Gifu University, Japan \\ ${ }^{2}$ IRIDeS, Laboratory of Regional Safety Engineering, Tohoku University, Japan
}

\begin{abstract}
It is commonplace that the ground near river is thickly covered with soft clay. Thus, in order to prevent it from the natural hazard, it is necessary that local people construct a robust embankment of countermeasure by constructing river bank in the soft ground, with low level of bearing capacity. To solve the problem aforementioned, local people are widely known to apply traditional method such as timber or bamboo pile. To establish this method, the Ministry of Public Works has published a technical guideline for reinforced soft ground before embankment. The guideline shows the process of mattress construction including: 1) cutting the ground for site preparation; 2) installing timber piles; 3) laying geo-grid on top of the piles and; 4) putting and compacting a granular material on the geo-grid. The guideline assists engineers to construct an embankment on the mattress. Unfortunately, the guideline never details a reasonable design based on geotechnical engineering. Hence, this paper aims to propose and discuss, a criterion of bearing capacity of reinforced soft clay using several empirical calculations. The model cases were simulated for small footings subjected by static loading on the mattress. As a result, the calculations will lead to the criterion of allowable bearing capacity of reinforced soft clay with timber pile.
\end{abstract}

\section{Introduction}

Flood and sea wave are two types of frequently occurring natural hazards in many Indonesian islands. More often than not, these hazards have led to severe damage to the residential areas located along the coast and dike of the rivers. However, despite the fact it is impossible to curb the occurrence of these natural hazards, it is possible to implement appropriate technologies to mitigate the severe impacts of these natural hazards.

The problems in the river dike in Indonesia are commonly conjured by two factors, such as natural and technical situation. A notable example of natural situation is seen in Sumatra Island which has almost all the typical problems in Indonesia such as thick soft soil, flood, earthquake and wave attack from sea or river.

This paper will address two cases of river dike in Indonesia, the dike of Tembilahan River and the dike of Siak River. Before being reconstructed for recovery 300 meters in length and 53 meters in width using concrete plate bridge on the concrete piles, the dike of Tembilahan River has previously collapsed due to heavy rain. The configurations of its construction were set up with the diameter $d=60 \mathrm{~cm}$, spacing of piles $s=2 \mathrm{~m}$ and $5 \mathrm{~m}$ on perpendicular and parallel to the river dike direction, respectively [1]. The dike of Tembilahan River after collapsing is shown in Figure 1.

The dike of Siak River has also been reconstructed by filling the embankment in length of $600 \mathrm{~m}$ to overcome flood hazards and wave attack from the surrounding river.

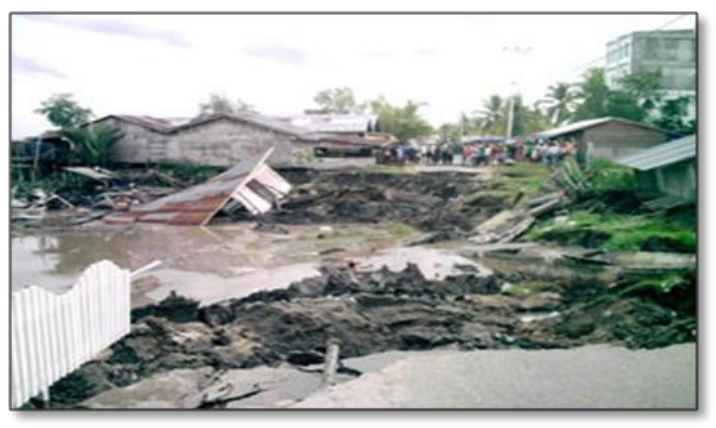

Fig.1. The visual conditions of Tembilahan River dike after collapsing

The CPT and SPT tests were conducted to investigate the depth of subsoil of $H_{s}=21 \mathrm{~m}$ and $H_{s}=12 \mathrm{~m}$ at Tembilahan and Siak River dike, respectively. The results of these tests are listed in Table 1. Table 1 shows the level of soft clay of $N$-SPT of $1 \sim 4$ for Tembilahan River and Siak River, which means that soft clay might have a consistency with undrained cohesive of soil $c_{u}$ less than $25 \mathrm{kPa}$ [2]. In order to increase the bearing capacity of soft soil, a traditional method of reinforcement called Cerucuk from timber or bamboo pile was implemented by Indonesian local people. Timber pile was installed into soft soil for reinforcement prior to construction of dike. Where $q_{n c}$ is uncorrected cone resistance, N-SPT is the number of blows.

\footnotetext{
Corresponding author: suyutinurdin@ymail.com
} 
Table 1.The results of CPT and SPT tests $[1,3]$

\begin{tabular}{|c|c|c|c|c|}
\hline River case & $\begin{array}{c}\mathrm{CPT}, q_{n c} \\
\left(\mathrm{~kg} / \mathrm{cm}^{2}\right)\end{array}$ & N-SPT & $\begin{array}{c}H_{s} \\
(\mathrm{~m})\end{array}$ & $\begin{array}{c}\text { Soil } \\
\text { consistency }\end{array}$ \\
\hline Tembilahan & $1 \sim 3$ & $1 \sim 3$ & 21 & Soft clay \\
\hline Siak & $1 \sim 5$ & $1 \sim 4$ & 12 & Soft clay \\
\hline
\end{tabular}

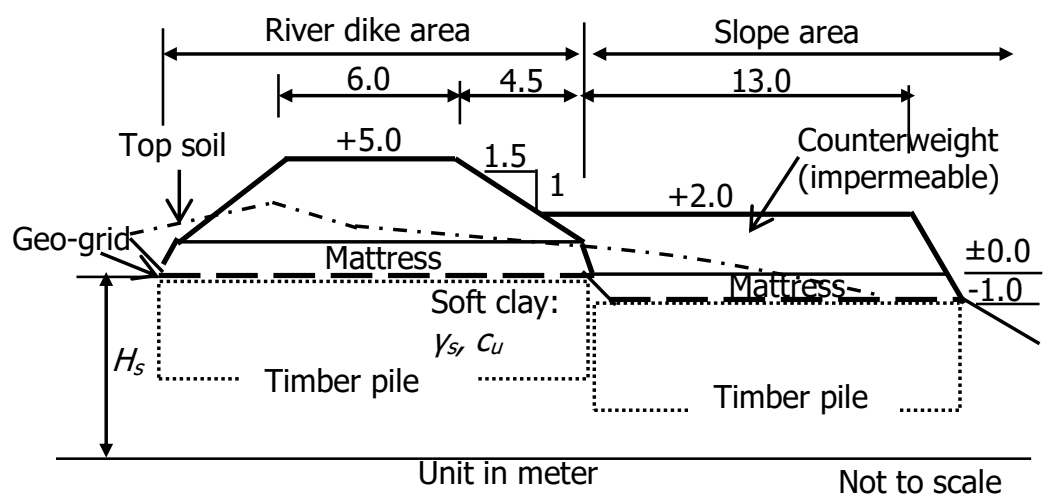

Fig.2. Cross section design of dike at Siak River

Table 2. Subsoil properties at Tembilahan River [1]

\begin{tabular}{|c|c|c|c|}
\hline \multirow{2}{*}{ Depth, $H_{s}(\mathrm{~m})$} & \multicolumn{2}{|c|}{ Soil properties } & \multirow{2}{*}{ Remark } \\
\cline { 2 - 3 } & $y_{s}\left(\mathrm{kN} / \mathrm{m}^{3}\right)$ & $c_{u}(\mathrm{kPa})$ & \\
\hline $0.0 \sim 6.0$ & 14.8 & 18 & Soft clay-1 \\
\hline $6.0 \sim 21.0$ & 16.0 & 10 & Very soft clay-2 \\
\hline $21.0 \sim 23.0$ & 16.8 & 25 & Medium clay \\
\hline $23.0 \sim 30.0$ & 17.2 & 5 & Sand \\
\hline $30.0 \sim 45.0$ & 17.5 & 23 & Stiff clay \\
\hline
\end{tabular}

However, it appears that the implementation of this traditional method on soft soil for technical situation, a design of the dike of Siak River with the implementation of timber pile installation has never existed in Indonesian design code.

The construction process of the implementation of Siak River dike included, i.e.

(a) cutting the ground for site preparation,

(b) installing timber pile,

(c) laying geo-grid on the ground surface,

(d) putting granular material and compacting as mattress for distributing load pressure, and

(e) filling up embankment (dike).

Figure 2 shows the typically designed dike construction of Siak River [3]. Where $H_{s}$ is the thickness of soft clay; $\gamma_{s}, C_{u}, \phi_{s}$ are the unit weight of soil; the undrained cohesive of soil, and the angle of internal friction of soil $\left(\phi_{s} \approx 0^{\circ}\right)$, respectively.

By using commercial software, the calculation results of the safety factors $F s$ for the slope of Siak River dike were reported $F_{S}$ from 1.21 to 1.36 [3]. To present a traditional construction method, a reasonable design rule conducting subsoil data at Tembilahan River dike is listed in Table 2.

The soil sample of two boreholes were conducted at the laboratory, and it reveals soft clay layers by high plasticity Index, $P I$ ( $P I$ more than
$40 \%)$. The ground water table in field data was at the same level as ground surface.

\section{Research objectives}

To identify the geotechnical problems for the stability performance of the river dike on soft soils, the traditional construction method aims to do the following things (1) installing timber pile in soft clay for improvement; (2) laying geo-grid beneath mattress for reinforcement; and (3) spreading granular as mattress beneath embankment.

A reasonable design rule based on geotechnics, the ultimate bearing capacity for mattress overlying soft clay is calculated by using empirical calculation method as presented below. The flow chart of the research is shown in Figure 3.

Load spreading within mattress through to the suface of ground was approximated by using value of slope of load spreading. The ultimate bearing capacity of mattress overlying soft clay for unreinforced and reinforced were studied, which was carried by small width of footing [4].

The Ministry of Public Works has published guideline on how to construct the embankment on mattress on soft soils or peat soil, by placing the mattress on top of timber or bamboo pile installation $[5,6]$. However, the guidelines are too difficult to apply by Indonesian local, because the design scheme of its calculation guideline of design was not written in a reasonable way. 
Therefore, several researchers had studied empirical analyses for determining the ultimate bearing capacity of sand overlying soft clay reinforced by geo-textile, which was conducted by footing the width it used from two tires of truck vehicle ([3, 4, 7, 8], [9-11]).

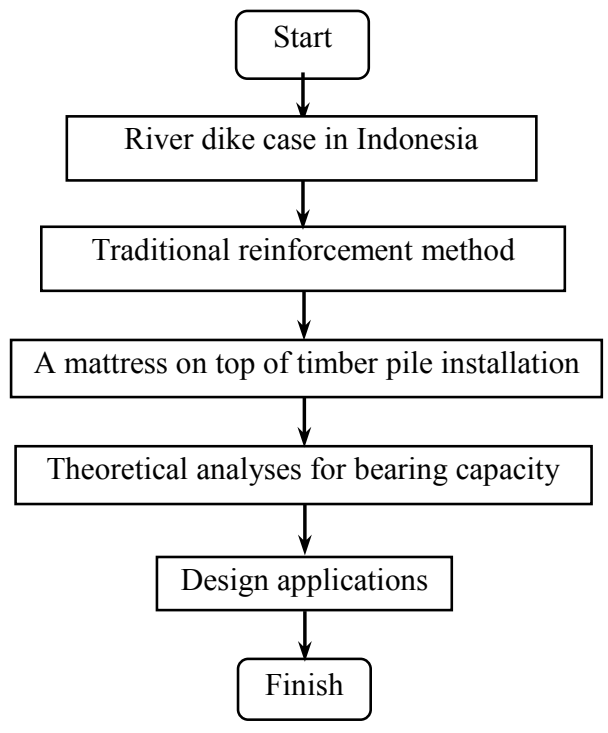

Fig. 3. Flow chart diagram for research objective

In these theoretical analyses, a static load pressure was loaded on the mattress overlying soft clay, which was supported by timber pile. To express point load $P_{0 r}$ on both sides, the load pressure was derived from truck vehicle on the rear axle for four tires. The point load of $P_{0 r}$ can be defined in two tires $P_{0 r}=1 / 3 W_{T}$, in which $W_{T}$ is assumed to be fully weighted [12]. The detail expression of point load $P_{0 r}$ is shown in figure 4.

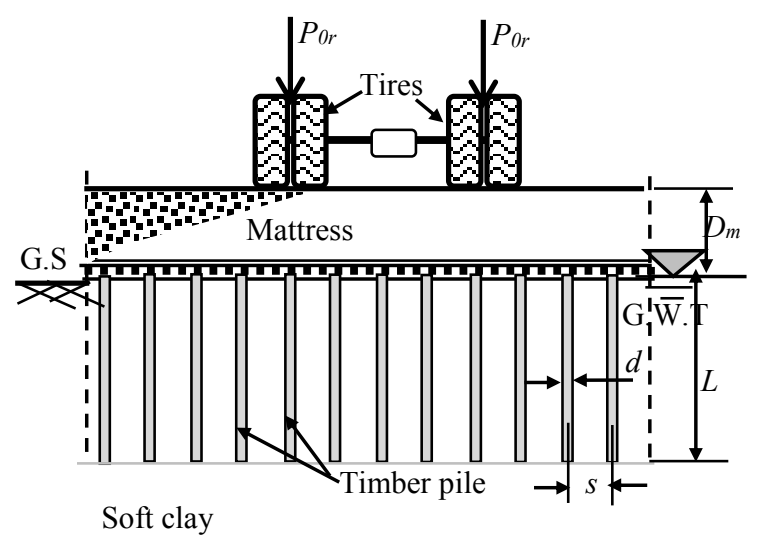

Fig. 4. Truck vehicle was applied on the mattress overlying soft clay improved with timber pile

Where $L$ is the embedded length of pile in soil; $d$ is the diameter of pile; $s$ is the spacing between piles set up in square pattern; G.W.T is groundwater table; $2 B_{0}$ is the width of load pressure; $D_{m}$ is the thickness of mattress.

The construction of the mattress overlying soft clay is considered by two-layered soil system, which installed the timber pile. Thus, the construction process of its mattress was done according to the traditional method in Indonesia. The design criterion of traditional construction method was provided by using several empirical analyses as follows.

\section{Theoretical analyses}

\subsection{Distribution of load pressure}

A mattress is overlying soft clay with geo-grid. The load pressure is distributed to ground surface, and the expression of this term is shown in figure 5 [13].

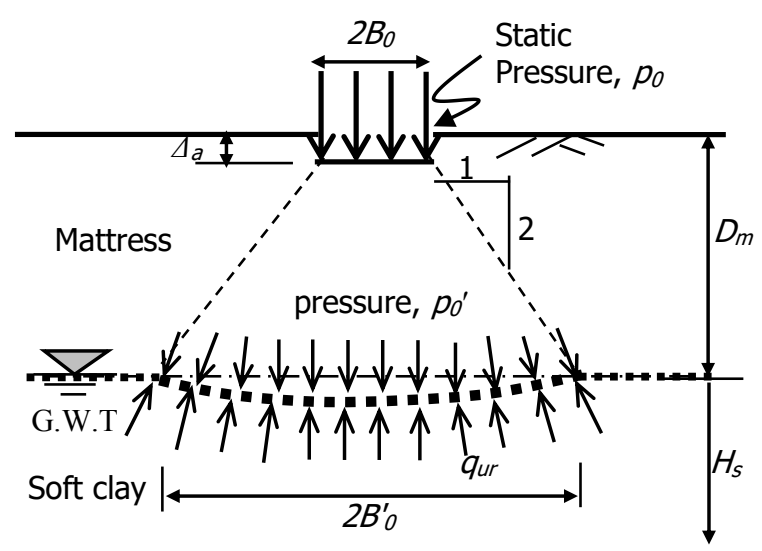

Fig. 5. Load pressure from truck vehicle was applied on the mattress overlying soft clay

Where $p_{0}{ }^{\prime}$ is the load pressure distribution applied at the ground surface; $q_{0}$ is the ultimate bearing capacity of original soft clay; $\Delta_{a}$ is the vertical deformation allowed under loading pressure [6].

The total pressure distributed $p_{0}{ }^{\prime}$ at the ground surface is more than or equal to the allowable bearing capacity of soft ground with reinforcement $q_{a r}$, which may be written as $[14,15]$

$$
\begin{gathered}
p_{0}{ }^{\prime}=q_{a r} \\
p_{0}{ }^{\prime}=p_{0} \frac{\left(2 B_{0} \times L_{0}\right)}{\left(2 B_{0}^{\prime} \times L_{0}^{\prime}\right)}+\left(D_{m}-\Delta_{a}\right) \gamma_{m} \\
q_{a r}=\frac{q_{u r}}{F s}
\end{gathered}
$$

Where $\gamma_{m}$ is the unit weight of mattress; $L_{0}$ is the length of load pressure; $2 B_{0}^{\prime}$ is the width of load spreading at the ground surface $\left(2 B_{0}^{\prime}=2 B_{0}+\left(D_{m}-\Delta_{a}\right)\right)$; $L^{\prime}{ }_{0}$ is the length of load spreading at the ground surface $\left(L_{0}^{\prime}=L_{0}+\left(D_{m}-\Delta_{a}\right)\right), F_{S}$ is factor of safety [15].

The reinforced soft ground system using geo-grid on the installed timber pile, maybe expressed in figure 6 . From figure 5 and 6 , the ultimate bearing capacities of soft clay is with reinforcement $q_{u r}$. The ultimate bearing capacity of mattress overlying soft clay reinforced by geo-grid and timber piles $q_{u r}$ lead to a simple formula to calculate the criterion of bearing capacity, which can be written as follows, 


$$
q_{u r}=q_{g}+q_{p}
$$

The ultimate bearing capacity of soft clay with reinforcement $q_{u r}$ is expressed in figure 7 .

Figure 7 shows the design capacity, in which $q_{a r}$ is the allowable bearing capacity of soft clay withreinforcement related to deformation $\Delta_{a} ; \Delta_{a}$ is the allowable deformation for bearing capacity.

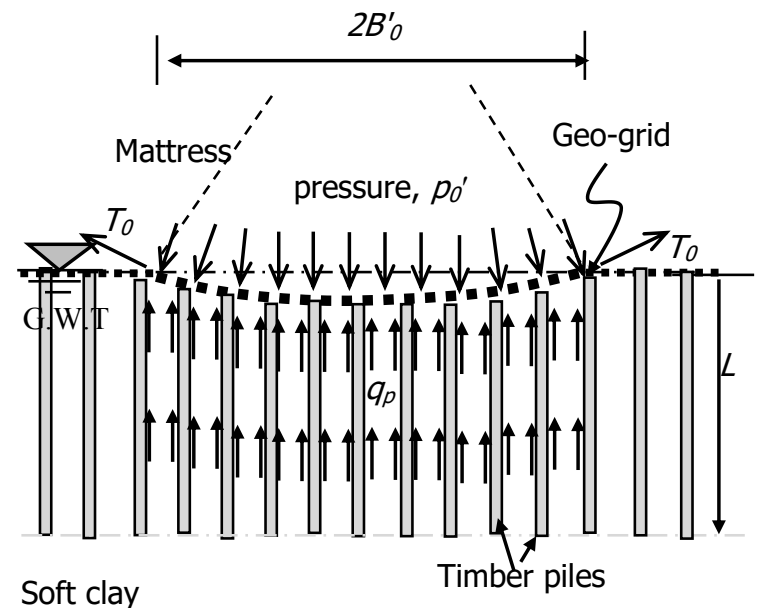

Fig. 6. Load pressure distribution on rested by geo-grid and timber pile installation

Where $T_{0}$ is the tensile strength of geo-grid; $q_{p}$ is the friction capacity of timber pile driven in the ground.

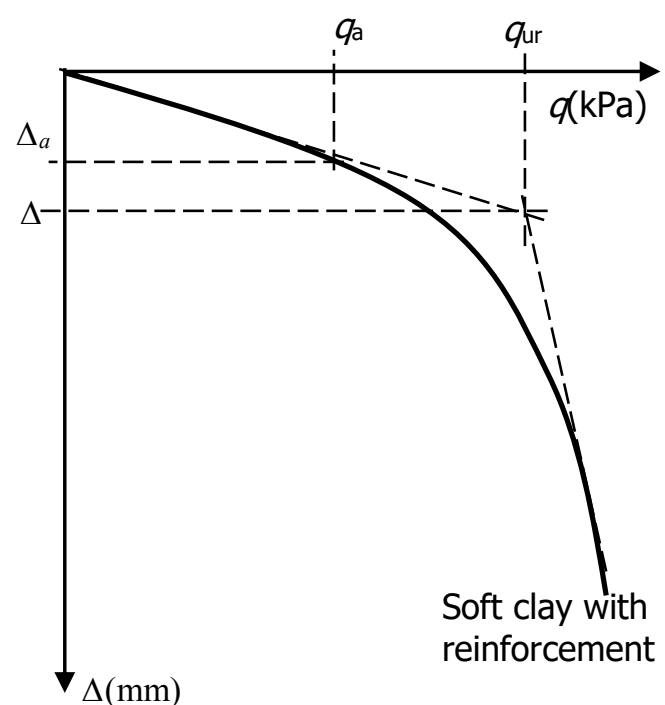

Fig.7. The correlation between the bearing capacity of mattress and the vertical deformation

\subsection{The Ultimate bearing capacity of reinforced soil}

A mechanism of calculation of the tensile capacity of geo-grid beneath the mattress is derived from the assumption about the allowed deformation at the top of mattress $\Delta_{a}$ and its equal deformation beneath the mattress. The expression of this term is shown in figure 8 .

Figure 8(a) shows that approximation of calculation and, the tensile capacity of geo-grid and frictional capacity of pile driven in clay are as explained below.

\subsubsection{Tensile capacity of geo-grid}

There are three considered categories for calculating criterion of geo-grid laid beneath the mattress including:

(a) Normal stress supported by geo-grid,

(b) Interfacial shear stress along the geo-grid, and

(c) Subgrade shear stress with effect of the geo-grid.

Figure 8 shows that the expression of deformation was explicitly presented for sand layer with geo-textile, which is applied for geo-grid at the ground surface for width footing $2 B^{\prime}{ }_{0}[10,11]$. The tensile capacity of geogrid $q_{g}$ for width spreading footing $2 B_{0}^{\prime}$ is given by

$$
q_{g}=\frac{1}{2 B_{0}^{\prime}}\left(T_{0} \sin \theta_{0}+\Delta_{a}\left[p_{m}+\frac{2 B_{0}}{2 B_{0}^{\prime}} p_{0}\right] \tan \psi\right)
$$

The angle of inclination at point-D $\theta_{0}$ is [6],

$$
\theta_{0}=\tan ^{-1}\left(\frac{4 \alpha_{\Delta}}{1-\left(2 \alpha_{\Delta}\right)^{2}}\right)
$$

The interface friction of the mattress to geo-grid $\psi$ is calculated by,

$$
\psi=\tan ^{-1}\left(\frac{D_{m}\left[K_{a m}-K_{p m}\right]+\frac{p_{0}}{p_{m}}\left[\eta K_{a m}-\tan \delta\right]}{\left[1+\frac{p_{0}}{p_{m}}\left(B_{0} / B_{0}^{\prime}\right)\right] 2 B_{{ }_{0}^{\prime}}}\right)
$$

Where $\theta_{0}$ is the angle of inclination at point $\mathrm{D}\left(^{\circ}\right) ; \eta$ is dimensionless factor; $\left(\eta=\left[2 \ln \left(B_{0}^{\prime} / B_{0}\right)\right]\right) ; \delta$ is the angle roughness of mattress to the tyre; $\alpha_{\Delta}$ is deformation factor $\left(\alpha_{\Delta}=\Delta_{a} / 2 B^{\prime}\right)$.

\subsubsection{Pile capacity driven in clay}

To predict the pile capacity driven in clay, the research focused on clay with normally consolidated material. The friction capacity of pile in clay $q_{p}$ for width of footing $2 B_{0}^{\prime}$ is resulted from $[16,17]$

$$
q_{p}=\alpha_{p} \times\left(2 B^{\prime}{ }_{0} / s\right) c_{u}
$$

$$
\alpha_{p}=0.55\left(\frac{L}{40 d}\right)^{-0.2} \times\left(\frac{\sigma_{v 0}^{\prime}}{c_{u}}\right)^{0,3}
$$

Where $\gamma_{s}$ is the unit weight of saturated soil; $\gamma_{w}$ is the unit weight of water; $\sigma_{v 0}{ }^{\prime}$ is the soil effective vertical $\operatorname{stress}\left(\sigma_{v 0} 0^{\prime}=L \times\left(\gamma_{s}-\gamma_{w}\right)\right)$. 


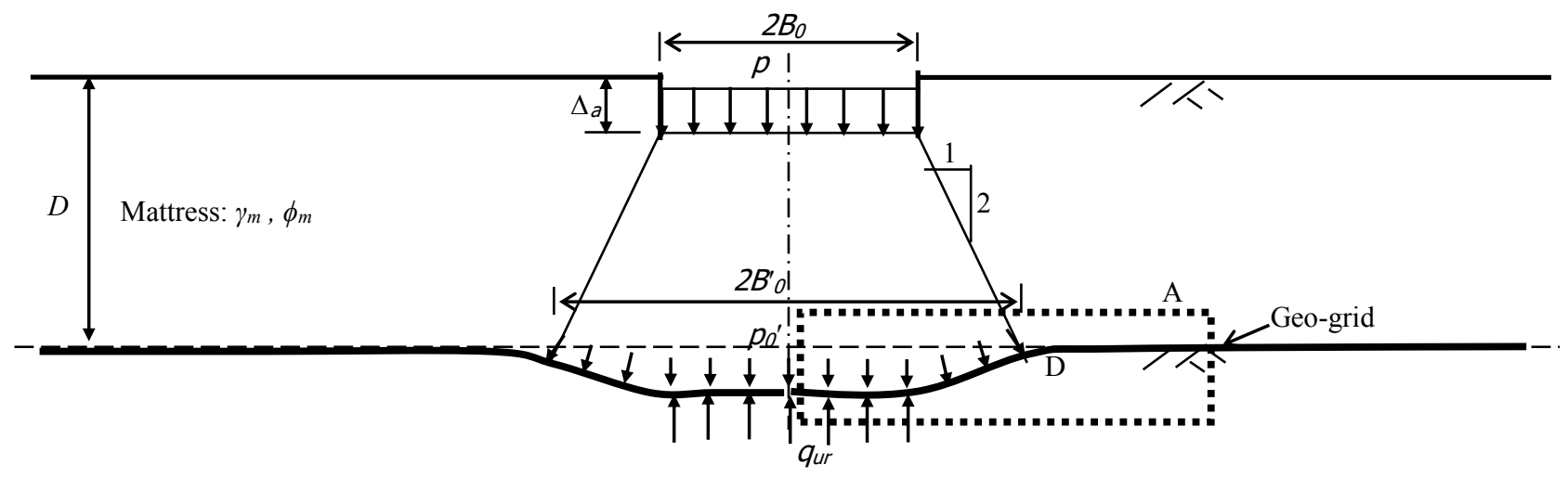

Soft clay: $c_{u}, \phi_{s}$

a. The expression mechanism of ultimate bearing capacity of mattress overlying soft clay

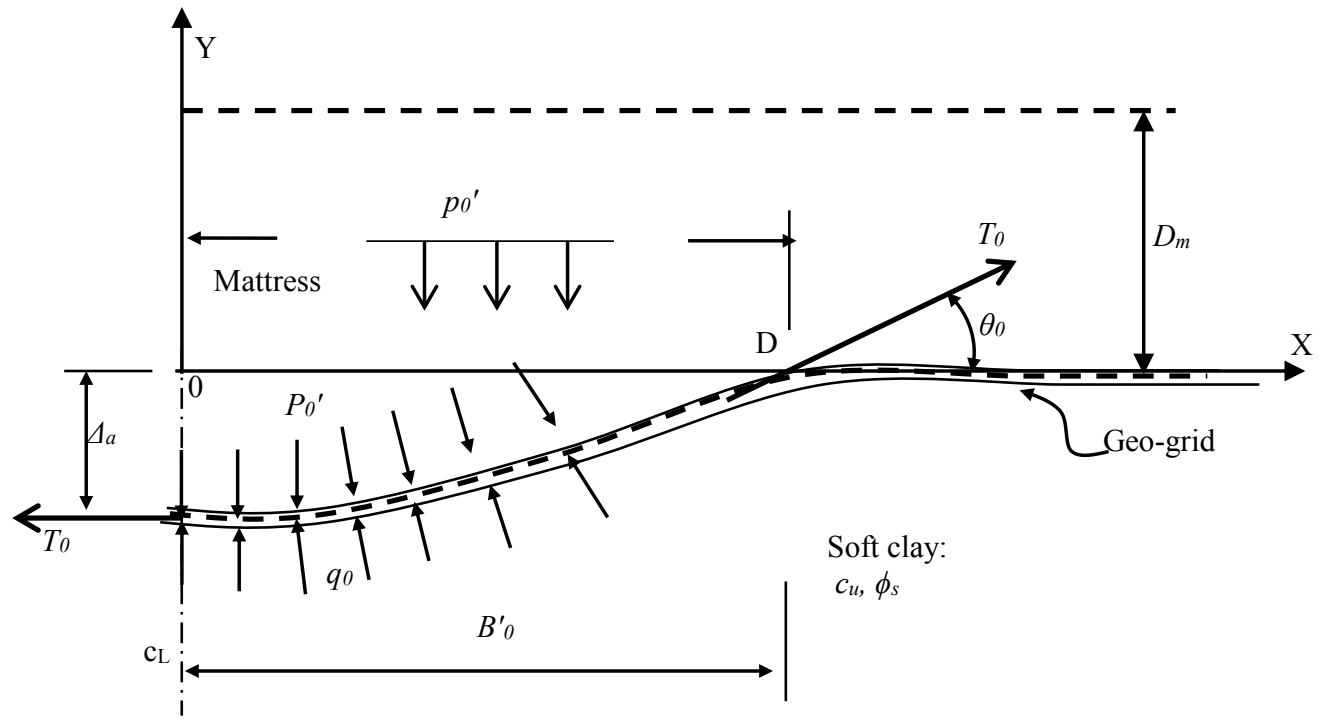

b. Detailed A - Deformed shape and stress acting of the geo-grid beneath the mattress

Fig.8. Expressions of mattress overlying soft clay reinforced by geo-grid

\subsection{Loading pressure on the mattress}

By using quasi - static method, the dimension of load pressure on the mattress was formed by assuming that the contact area of tire is a rectangle footing. The intensity of load pressure $p_{0}$ at the mattress surface is expressed by

$$
p_{0}=\frac{P_{0 r}}{2 B_{0} \times L_{0}}
$$

\section{Design applications}

The proposal empirical method for calculating criterions of reinforced soft ground were examined, and resulted in soft clay down with the depth of $21 \mathrm{~m}$ at Tembilahan River dike. The parameters of soft clay lead to the cohesion $c_{u}$ of $18 \mathrm{kPa}$ and submerged unit weight $\gamma_{s}$ of $14.8 \mathrm{kN} / \mathrm{m}^{3}$ [1]. Dimensions and parameters of the mattress resulted in such as $\gamma_{m}=20.5 \mathrm{kN} / \mathrm{m}^{3} ; D_{m}=0.2 \mathrm{~m}$ $\sim 0.8 \mathrm{~m} ; N_{c}=5.14$ and taken into calculation $F_{S}=2.0$, $[7,15]$. The timber pile is installed in square pattern, and its design is limited in parameters such as spacing $s(s=$ $3 \mathrm{~d}, 5 \mathrm{~d}, 7 \mathrm{~d}), d=8 \mathrm{~cm}$ and $10 \mathrm{~cm} ; L=3 \mathrm{~m}$ and $4.5 \mathrm{~m}$; as well as laid geo-grid of piles with tensile strength $T_{0}$ of $24 \mathrm{kN} / \mathrm{m}[3,6]$.

Load pressure of small footing $p_{0}$ was contacted at the mattress, and it led to $p_{0}$ of $205.05 \mathrm{kPa}$, which was calculated by point load $P_{0 r}$ of $26.7 \mathrm{kN}$ with area of $2 B_{0}$ of $0.51 \mathrm{~m}$ in width and $L_{0}$ of $0.255 \mathrm{~m}$ in length $[3,12]$.

The load pressure distribution $p_{0}^{\prime}$ is through the allowable bearing capacity of reinforced subsoil system for $d$ of $8 \mathrm{~cm}, 10 \mathrm{~cm}$ and varied spacing and length of piles resulted in the followings as shown in figures of 9 to 12 .

Figure 9 shows that the criterion of allowable bearing capacities $q_{a r}$ were found to be less than the load pressure $p_{0}{ }^{\prime}$ for cohesion $c_{u}$ of $18 \mathrm{kPa}$ and $25 \mathrm{kPa}$ and all of thickness of mattress $D_{m}$ except cohesion $c_{u}$ of $25 \mathrm{kPa}$ and mattresss $D_{m}$ of $0.50 \mathrm{~m}$ to $0.80 \mathrm{~m}$ on timber piles with spacing $s$ of $3 \mathrm{~d}$. When the spacing of piles as shown in figure 10 was made longer $(L=4.5 \mathrm{~m})$, the allowable 
bearing capacities $q_{a r}$ increased $q_{a r}$ up to $43.19 \mathrm{kPa}$ for cohesion $c_{u}$ of $25 \mathrm{kPa}$ and spacing of pile $s$ of $3 \mathrm{~d}$.

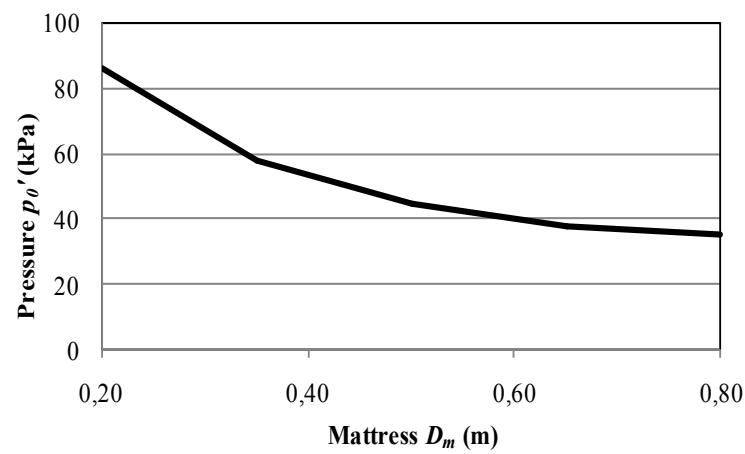

a. Pressure $p_{0}{ }^{\prime}$ vs mattress $D_{m}$

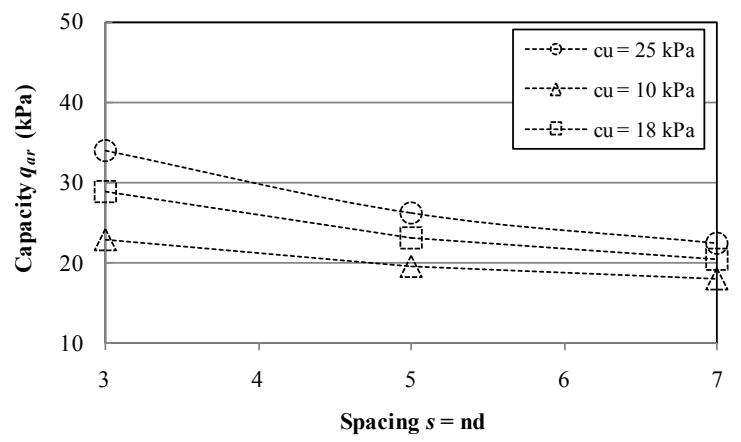

b. Capacity $q_{a r}$ vs spacing $s=\mathrm{nd}$ ( for $D_{m}=0.20 \mathrm{~m}$ )

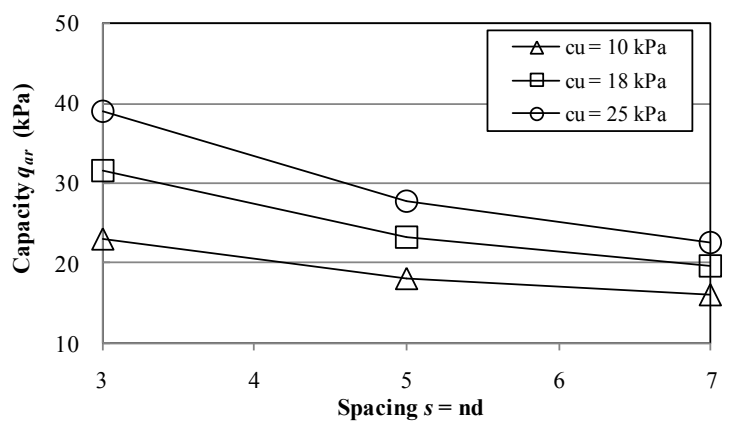

C. Capacity $q_{a r}$ Vs spacing $s=$ nd ( for $D_{m}=0.50 \mathrm{~m}$ )

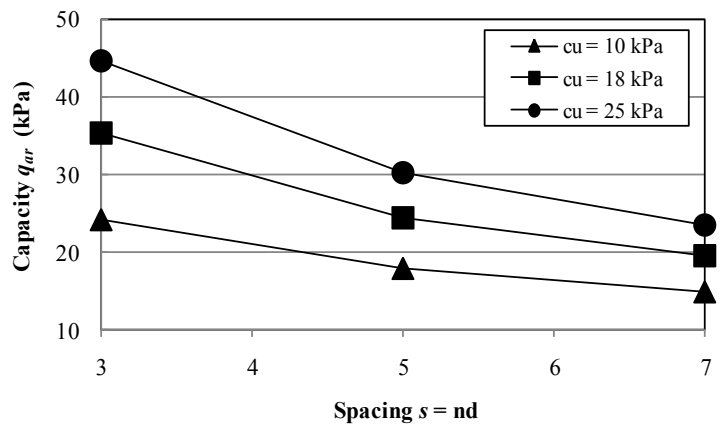

d. Capacity $q_{a r}$ vs spacing $s=n d$ ( for $D_{m}=0.80 \mathrm{~m}$ )

Fig.9. Criterion of reinforced soft clay using geo-grid and timber pile ( for $d=8 \mathrm{~cm}, L=3 \mathrm{~m}, n=3,5,7$ )

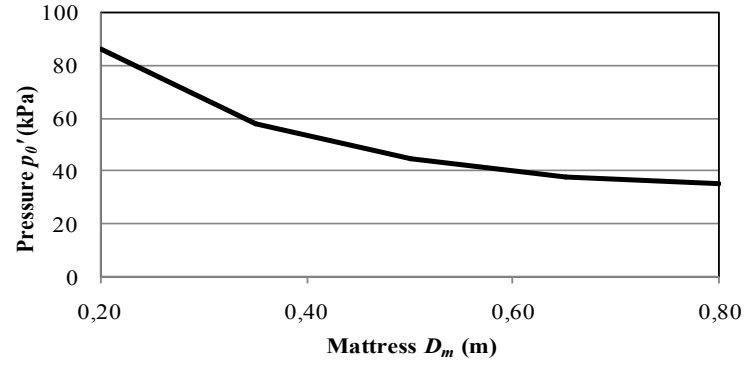

a. Pressure $p_{0}{ }^{\prime}$ vs mattress $D_{m}$

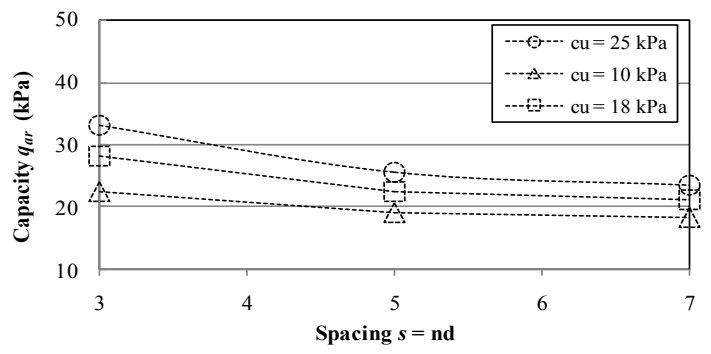

b. Capacity $q_{a r}$ vs spacing $s=$ nd ( for $D_{m}=0.20 \mathrm{~m}$ )

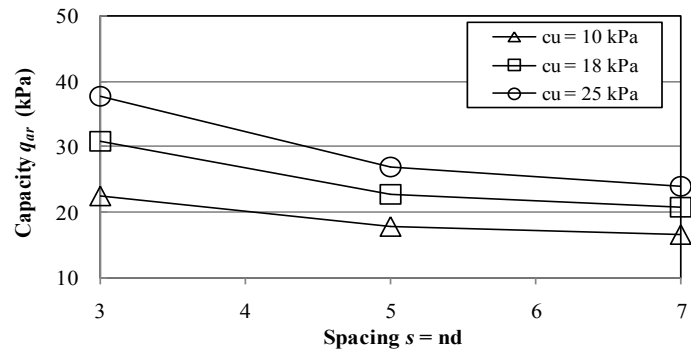

C. Capacity $q_{a r}$ vs spacing $s=$ nd ( for $D_{m}=0.50 \mathrm{~m}$ )

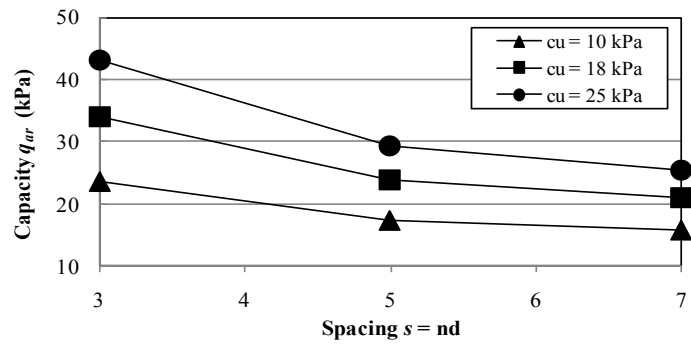

d. Capacity $q_{a r}$ vs spacing $s=n d$ ( for $D_{m}=0.80 \mathrm{~m}$ )

Fig.10. Criterion of reinforced soft clay using geo-grid and timber pile ( for $d=8 \mathrm{~cm}, L=4.5 \mathrm{~m}, n=3,5,7$ )

Figure of 11 and 12 show that the criterion of allowable bearing capacities $q_{a r}$ led to $q_{a r}$ of $38.84 \mathrm{kPa}$ more than the load pressure $p_{0}$ 'only for mattress $D_{m}$ of $0.80 \mathrm{~m}$ on cohesion $c_{u}$ of $25 \mathrm{kPa}$ that improved timber pile (with spacing $s=3 \mathrm{~d}, d=10 \mathrm{~cm}, L=3 \mathrm{~m}$ ). However, the length of pile was made longer by $L$ of $4.5 \mathrm{~m}$, the criterion of allowable bearing capacity of reinforced soft clay $q_{a r}$ was sufficient only $q_{a r}$ of $37.51 \mathrm{kPa}$ for cohesion $c_{u}$ of $25 \mathrm{kPa}$, and mattress $D_{m}$ of 0.80 .

The design criterion of allowable bearing capacity of reinforced soft clay was compared as summarized in table 3 . 
Table 3. Summary of $q_{a r}$ for reinforced soft clay with $c_{u}=25$ $\mathrm{kPa}$ and mattress $D_{m}=0.80 \mathrm{~m}\left(p_{0}{ }^{\prime}=35.17 \mathrm{kPa}\right)$

\begin{tabular}{|c|c|c|c|}
\hline \multicolumn{2}{|c|}{ Reinforced soft clay } & $\begin{array}{c}\text { Capacity, } \\
q_{a r}(\mathrm{kPa})\end{array}$ & Remark \\
\hline Geo-grid on piles & $L=3 \mathrm{~m}$ & 44.77 & $q_{a r}>p 0^{\prime}$ \\
\cline { 2 - 4 }$s=3 \mathrm{~d}, d=8 \mathrm{~cm}$ & $L=4.5 \mathrm{~m}$ & 43.19 & $q_{a r}>p 0^{\prime}$ \\
\hline Geo-grid on piles & $L=3 \mathrm{~m}$ & 30.25 & $q_{a r}<p 0^{\prime}$ \\
\cline { 2 - 4 }$s=5 \mathrm{~d}, d=8 \mathrm{~cm}$ & $L=4.5 \mathrm{~m}$ & 29.29 & $q_{a r}<p 0^{\prime}$ \\
\hline $\begin{array}{c}\text { Geo-grid on piles } \\
s=3 \mathrm{~d}, d=10 \mathrm{~cm}\end{array}$ & $L=3 \mathrm{~m}$ & 38.84 & $q_{a r}>p 0^{\prime}$ \\
\cline { 2 - 4 } $\begin{array}{c}\text { Geo-grid on piles } \\
s=5 \mathrm{~d}, d=10 \mathrm{~cm}\end{array}$ & $L=3 \mathrm{~m}$ & 37.51 & $q_{a r}>p 0^{\prime}$ \\
\cline { 2 - 4 } & $L=4.5 \mathrm{~m}$ & 26.68 & $q_{a r}<p 0^{\prime}$ \\
\hline
\end{tabular}

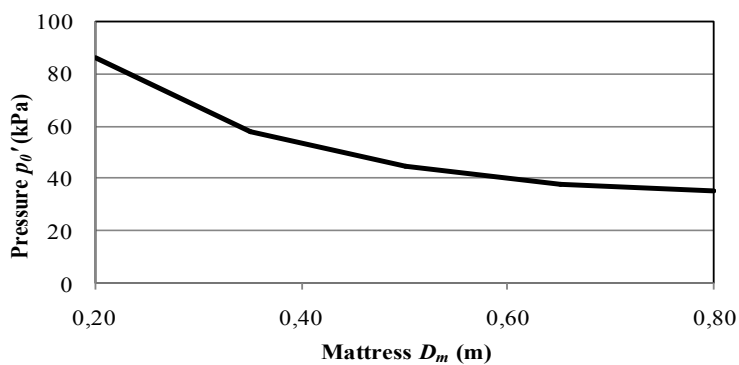

a. Pressure $p_{0}{ }^{\prime}$ vs mattress $D_{m}$

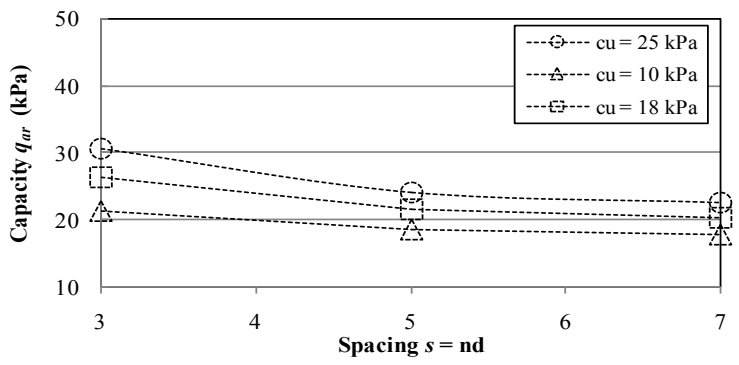

b. Capacity $q_{a r}$ vs spacing $s=$ nd ( for $D_{m}=0.20 \mathrm{~m}$ )

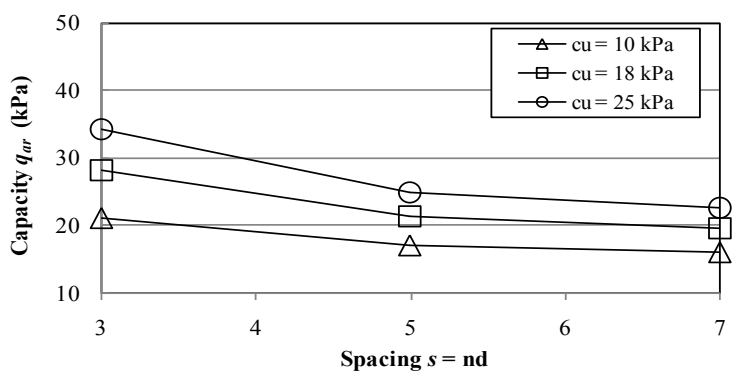

C. Capacity $q_{a r}$ vs spacing $s=$ nd ( for $D_{m}=0.50 \mathrm{~m}$ )

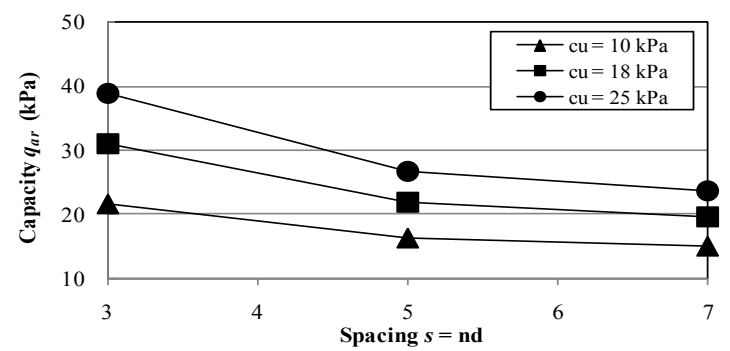

d. Capacity $q_{a r}$ vs spacing $s=n d$ ( for $D_{m}=0.80 \mathrm{~m}$ )

Fig.11. Criterion of reinforced soft clay using geo-grid and timber pile ( for $d=10 \mathrm{~cm}, L=3 \mathrm{~m}, n=3,5,7$ )

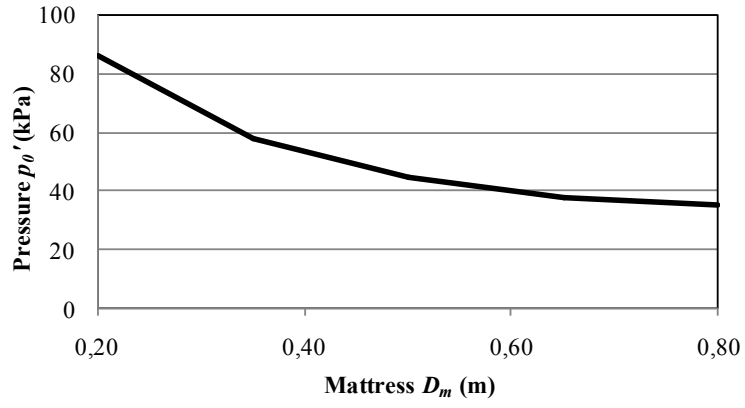

a. Pressure $p_{0}{ }^{\prime}$ vs mattress $D_{m}$

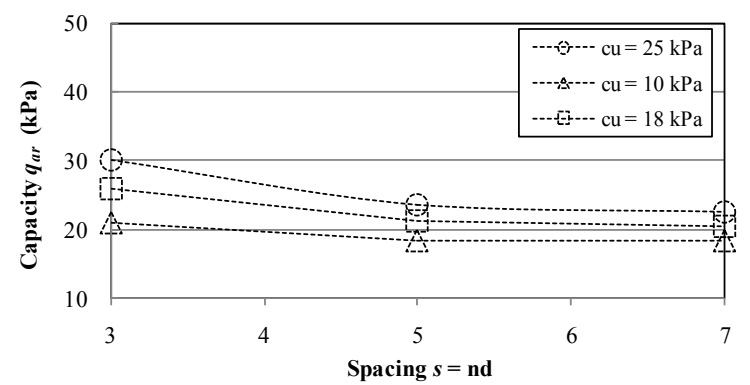

b. Capacity $q_{a r}$ vs spacing $s=$ nd ( for $D_{m}=0.20 \mathrm{~m}$ )

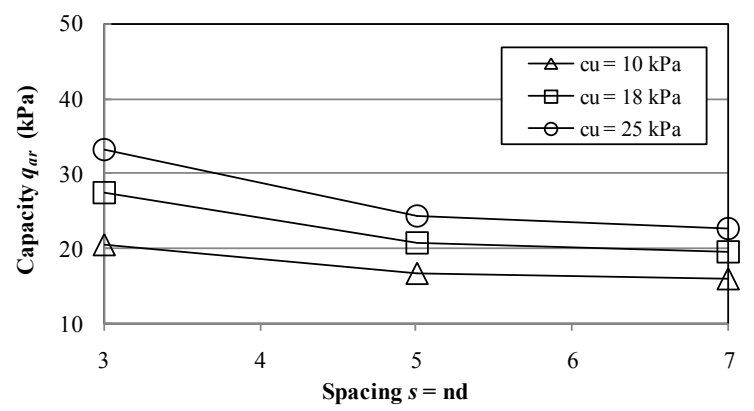

C. Capacity $q_{a r}$ vs spacing $s=\mathrm{nd}$ ( for $D_{m}=0.50 \mathrm{~m}$ )

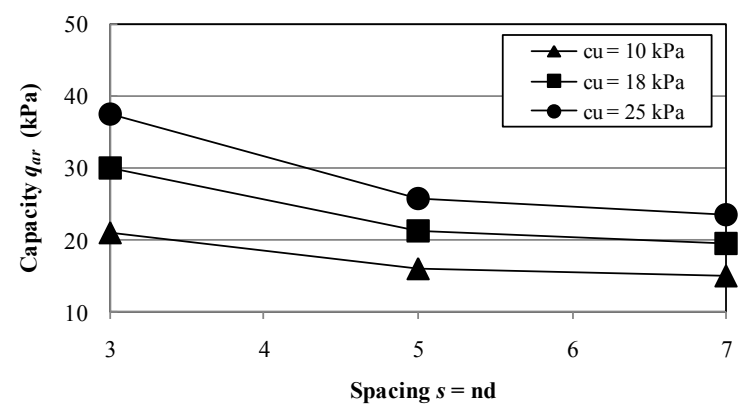

d. Capacity $q_{a r}$ vs spacing $s=n d$ ( for $D_{m}=0.80 \mathrm{~m}$ )

Fig.12. Criterion of reinforced soft clay using geo-grid and timber pile ( for $d=10 \mathrm{~cm}, L=4.5 \mathrm{~m}, n=3,5,7$ )

\section{Conclusions}

The pile was installed with small size diameter of $8 \mathrm{~cm}$ and spacing of pile was $\mathrm{s}=3$ diamaters which affected the larger size to increase the allowable bearing capacity for pile in length $L$ of $3.0 \mathrm{~m}$ or $L$ of $4.5 \mathrm{~m}$. It is sufficient 
to support load pressure $p_{0}{ }^{\prime}$ for cohesion of subsoil $c_{u}$, which is more than or equal to $c_{u}$ of $25 \mathrm{kPa}$.

Therefore, the pile size diameter of $8 \mathrm{~cm}$ and spacing of piles $s=3 \mathrm{~d}$ were appropriated to carry out a good criterion of the allowable bearing capacity of reinforced soft clay $q_{a r}$ for supporting load pressure as reported in the guideline [11].

\section{Acknowledgment}

The author would like extend gratitude for the Ministry of Research, Technology and Education of the Republic of Indonesia for the financial support of Doctoral scholarship.

\section{References}

1. Ministry of Public Works, Design Construction of River for Preventing Residences and Infrastructures at Tembilahan District, no.615/SRPD/contract/54/2008 (2008), In Indonesian

2. K. Terzaghi and R.B. Peck, Soil Mechanics in Engineering Practice, John \& Sons, Inc, 299 - 304 (1948)

3. Ministry of Public Works, Study Countermeasure Damage Against Geotechnical Construction at Siak River, Final report (2005), In Indonesian

4. H.J. Burd, Analysis of Membrane Action in Reinforced Unpaved Roads, Canadian Geotechnical Journal, 32, 946 - 956 (1995)

5. Ministry of Public Works, Construction Procedures for Timber or Bamboo Pile Foundation on Soft and Peat Soils, No.020/T/BM/1999 (1999), In Indonesian

6. Ministry of Public Works, Design and Construction for Road Embankment on Soft Soils, 1st EditionBook 4 $4^{\text {th }}$ No. Pd- T-10-2002-B (2002), In Indonesian

7. H.J. Burd and S. Frydman, Bearing Capacity of Plane - Strain Footings on Layered Soils, Canadian Geotechnical Journal, 34, 241-253 (1997)

8. J.P. Giroud and L. Noiray, Geotextile Reinforced Unpaved Road Design, Journal of The Geotechnical Engineering Division, 107(GT9), 1233 -1254 (1981)

9. P.L. Bordeau, Modelling of Membrane Action in A Two-Layer Reinforced Soil System, Computer and Geotechnics, Elsevier Publishers Ltd, England, 19 36 (1989)

10. R.D. Espinoza, Soil-Geotextile Interaction: Evaluation of Membrane Support, Geotextiles and Geomembrane, 13(5), 281 - 293 (1994)

11. R.D. Espinoza and J.D. Bray, An Integrated Approach to Evaluating Single-Layer Reinforced Soils, Geosynthetics International, 2(4), $723-739$, (1995)
12. R.J. Fannin and O. Sigurdsson, Field Observations on Stabilization of Unpaved Roads with Geosynthetics, Journal of Geotechnical Engineering, 122, 544 - 553, (1996)

13. G.W.E. Milligan, R.A. Jewell, G.T. Houlsby and H.J. Burd, A New Approach to The Design of Unpaved Roads-Part I. Ground Engineering, 22(3), 25 - 29 (1989)

14. H. Yamaguchi, Practical Formula of Bearing Capacity for Two Layered Ground, Proc.2nd Asian Regional Conference on Soil Mechanics and Foundation Engineering, Japanese Society of Soil Mechanics and Foundation Engineering, Tokyo, 1, $176-211$ (1963)

15. B.M. Das, Principles of Foundation Engineering, $4^{\text {th }}$ Edition, PWS Publishing, 152 - 159 (1999)

16. H.J. Kolk and E. van der Velde, A Reliable Method to Determine Friction Capacity of Piles Driven into Clays, In Proceeding of The Offshore Technology Conference, Houston, Tex., 337 - 346 (1996)

17. K. Gavin, K.D. Gallagher, Doherty, P and McCabe, $B$, Field Investigation of The Effect of Installation Method on The Shaft Resistance of Pile in Clay, Canadian Geotechnical J (47), 730 -741 (2010) 